\title{
Oral manifestations of HIV infection in children and adults receiving highly active anti-retroviral therapy [HAART] in Dar es Salaam,
}

\section{Tanzania}

\author{
Omar JM Hamza*1, Mecky IN Matee², Elison NM Simon¹, Emil Kikwilu³, \\ Mainen J Moshi ${ }^{4}$, Ferdinand Mugusi ${ }^{5}$, Frans HM Mikx ${ }^{6}$, Paul E Verweij ${ }^{7}$ and \\ André JAM van der Ven ${ }^{8}$
}

\begin{abstract}
Address: ${ }^{1}$ Department of Oral Surgery and Oral Pathology, Muhimbili University College of Health Sciences, Dar es Salaam, Tanzania, ${ }^{2}$ Department of Microbiology and Immunology, Muhimbili University College of Health Sciences, Dar es Salaam, Tanzania, ${ }^{3}$ Department of Preventive and Community Dentistry, Muhimbili University College of Health Sciences, Dar es Salaam, Tanzania, ${ }^{4}$ Institute of Traditional Medicine, Muhimbili University College of Health Sciences, Dar es Salaam, Tanzania, ${ }^{5}$ Department of Internal Medicine, Muhimbili University College of Health Sciences, Dar es Salaam, Tanzania, ${ }^{6}$ WHO Collaborating Center, Dentistry, Radboud University Nijmegen Medical Center, Nijmegen, The Netherlands, ${ }^{7}$ Department of Medical Microbiology, Radboud University Nijmegen Medical Center, Nijmegen, The Netherlands and ${ }^{8}$ Department of General Internal Medicine, Radboud University Nijmegen Medical Center, Nijmegen, The Netherlands
\end{abstract}

Email: Omar JM Hamza* - dromar20@yahoo.com; Mecky IN Matee - mmatee@muchs.ac.tz; Elison NM Simon - esmjema@yahoo.com; Emil Kikwilu - ekikwilu@muchs.ac.tz; Mainen J Moshi - mmoshi@muchs.ac.tz; Ferdinand Mugusi - fmugusi@muchs.ac.tz;

Frans HM Mikx - fransmikx@hotmail.com; Paul E Verweij - p.verweij@mmb.umcn.nl; André JAM van der Ven - a.vanderven@aig.umcn.nl

* Corresponding author

Published: 18 August 2006

BMC Oral Health 2006, 6:12 doi:10.1 186/1472-6831-6-12
Received: II May 2006

Accepted: 18 August 2006

This article is available from: http://www.biomedcentral.com//472-683//6/12

(C) 2006 Hamza et al; licensee BioMed Central Ltd.

This is an Open Access article distributed under the terms of the Creative Commons Attribution License (http://creativecommons.org/licenses/by/2.0), which permits unrestricted use, distribution, and reproduction in any medium, provided the original work is properly cited.

\begin{abstract}
Background: The aim of the study was to compare the prevalence and types of HIV-related oral lesions between children and adult Tanzanian patients on HAART with those not on HAART and to relate the occurrence of the lesions with anti-HIV drug regimen, clinical stage of HIV disease and CD4+ cell count.

Methods: Participants were 532 HIV infected patients, $5 \mathrm{I}$ children and $48 \mathrm{I}$ adults, 165 males and 367 females. Children were aged 2-17 years and adults 18 and 67 years. Participants were recruited consecutively at the Muhimbili National Hospital (MNH) HIV clinic from October 2004 to September 2005. Investigations included; interviews, physical examinations, HIV testing and enumeration of CD4+ T cells.
\end{abstract}

Results: A total of 237 HIV-associated oral lesions were observed in 210 (39.5\%) patients. Oral candidiasis was the commonest (23.5\%), followed by mucosal hyperpigmentation (4.7\%). There was a significant difference in the occurrence of oral candidiasis $\left(\chi^{2}=4.3 \mathrm{I} ; \mathrm{df}=\mathrm{I} ; \mathrm{p}=0.03\right)$ and parotid enlargement $\left(\chi^{2}=36.5 ; \mathrm{df}=\mathrm{I} ; \mathrm{p}=0.04\right)$ between children and adults. Adult patients who were on HAART had a significantly lower risk of; oral lesions (OR $=0.32 ; 95 \% \mathrm{Cl}=0.22$ $0.47 ; p=0.005)$, oral candidiasis $(O R=0.28 ; 95 \% \mathrm{Cl}=0.18-0.44 ; p=0.003)$ and oral hairy leukoplakia $(O R=0.18 ; 95 \%$ $\mathrm{Cl}=0.04-0.85 ; p=0.03$ ). There was no significant reduction in occurrence of oral lesions in children on HAART (OR $=0.35 ; 95 \% \mathrm{Cl}=0.1 \mathrm{I}-\mathrm{I} .14 ; \mathrm{p}=0.15)$. There was also a significant association between the presence of oral lesions and CD4+ cell count $<200$ cell $/ \mathrm{mm}^{3}\left(\chi^{2}=52.4 ; \mathrm{df}=2 ; \mathrm{p}=0.006\right)$ and with WHO clinical stage $\left(\chi^{2}=12 \mathrm{I} ; \mathrm{df}=3 ; \mathrm{p}=0.008\right)$. Oral lesions were also associated with tobacco smoking $\left(\chi^{2}=8.17 ; \mathrm{df}=2 ; \mathrm{p}=0.04\right)$.

Conclusion: Adult patients receiving HAART had a significantly lower prevalence of oral lesions, particularly oral candidiasis and oral hairy leukoplakia. There was no significant change in occurrence of oral lesions in children receiving 
HAART. The occurrence of oral lesions, in both HAART and non-HAART patients, correlated with WHO clinical staging and CD4+ less than 200 cells $/ \mathrm{mm}^{3}$.

\section{Background}

Most African studies on HIV associated oral lesions have been done during pre-HAART era [1-11]. The relatively few studies of oral lesions in patients on HAART have been conducted elsewhere and do indicate significant differences in the influence of HAART on types of oral lesions [12-14]. For example, oral candidiasis, oral hairy leukoplakia, Kaposi's sarcoma and HIV-associated periodontal diseases have been reported to decrease $[12,13,15$ 22]. On the other hand, HIV-salivary gland disease, human papilloma virus (HPV)-associated oral lesions including papilloma, condylomas and focal epithelial hyperplasia [oral warts], xerostomia and recurrent oral ulceration appear to have increased [13-15,18,23-25]. There are also reports indicating no change in the occurrence of HIV associated oral lesions in children receiving HAART [26,27]. The reasons for these differences are not entirely clear. Some authors have associated these variations with differences in access to oral health care, demographic and social factors, mode of HIV transmission, types of co-infections, disease stage and immune reconstitution $[18,28,29]$. Nonetheless, the presence of such significant differences underlines the need for meticulous monitoring of prevalence and types of HIV associated oral lesions in every clinical setting that provide HAART [13].

As indicated earlier, most of the above-mentioned studies have been conducted in developed countries [30,31]. There is relatively little information emanating from developing countries, where particular efforts are being made to scale up provision of HAART to eligible patients [32].

The government of Tanzania, with assistance from international donor agencies, started providing HAART to HIV patients free of charge in July 2004 [33,34]. However, there is no information regarding human immunodeficiency virus (HIV)-related oral lesions of patients on antiretroviral therapy. This study aimed to determine the prevalence and types of oral manifestations of HIV/AIDS between children and adult patients on HAART and those not on HAART, and correlate clinical oral lesions with clinical stage of HIV disease, anti-HIV drug regimen and CD4+ cell count.

\section{Methods}

\section{Participants and setting}

A total of 532 HIV-infected patients, 367 (69\%) females and $165(31 \%)$ males participated in the study. There were 51 children aged between 2 and 17 years, with mean age of $7.6(\mathrm{SD} \pm 4.3)$ years and 481 adults aged $18-67$ years, with a mean age of $38.2(S D \pm 8.9)$ years. Participants were recruited consecutively at the Muhimbili National Hospital (MNH) HIV clinic in Dar es Salaam, from October 2004 to September 2005. The MNH is the largest referral hospital in Tanzania and serves as a teaching facility for the Muhimbili University College of Health Sciences (MUCHS), the largest medical school in the country.

\section{Study design and sample size calculations}

This was a cross sectional study. The sample size was estimated at 336, by assuming the prevalence of oral lesions in HIV infected individuals in Tanzania to be around 30\% [4] and by setting type I error at 5\% and type II error at $20 \%$. We consecutively enrolled 532 patients. None of the patients declined participation in this study, bringing the participation rate to $100 \%$.

\section{Investigations}

Patients were interviewed using a standard structured questionnaire to obtain information regarding social and demographic details, past medical history, family history and history of previous medication. Previous episodes of oral candidiasis, other medical conditions, use of traditional medicine, anti-tuberculosis drugs, antifungal agents, and use of antiretroviral and current treatments were all recorded. Current and previous episodes of opportunistic systemic diseases related to HIV were categorized and recorded as follows: tuberculosis, pneumonia, herpes zoster infection and cryptococcal meningitis.

\section{General examination}

Clinical examination of all study patients was done by an independent physician, who categorized them in accordance with the World Health Organization (WHO) clinical staging criteria [35].

\section{Oral examination}

An oral examination was carried out by a qualified dental surgeon without knowing the HIV clinical stage and CD4+ cell count level of the patient or whether the patient was on HAART or not. A standard oral examination method recommended by WHO [36] was used to examine: (a) the extra-oral, head and neck areas; and (b), perioral and intra-oral soft tissues using a criteria described by Greenspan et al. [37]. Examination was conducted while the patient was seated on a chair under artificial light. The extra-oral and peri-oral tissues were examined first, followed by the intra-oral tissues, for changes in size, colour 
and shape of anatomical areas as well as for clinical signs and lesions. The oral lesions associated with HIV infection were diagnosed based on their clinical presentation and where multiple sites were involved, all sites were documented.

\section{HIV serology and determination of lymphocytes subsets} Blood was collected in EDTA tubes from the patients. HIV serology was determined by Vironostika HIV Uni-Form II $\mathrm{Ag} / \mathrm{Ab}$ (BioMerieux, Boxtel, The Netherlands) and reactive samples were retested by Vironostika HIV Uni-Form II Plus O (BioMerieux, Boxtel, The Netherlands). Samples reactive on both tests were considered to be positive for IgG anti HIV antibodies. Enumeration of CD4+ and CD8+ T cells was done using FACS count machine after staining patients' blood with monoclonal antibodies [38].

\section{HAART regimens}

In Tanzanian setting, a triple therapy consisting of 2 nucleoside reverse transcriptase inhibitors (NRTI) + 1 nonnucleoside reverse transcriptase inhibitors (NNRTI) or 2 NRTI + 1 Protease inhibitor (PI) is recommended. The first line includes four different combinations of drugs: stavudine + lamivudine + nevirapine; stavudine + lamivudine + effavirenz; zidovudine + lamivudine + nevirapine and zidovudine + lamivudine + effavirenz. The second line regimen includes the following drug combination: Abacavir + kaletra (lopinavir/ritonavir) + didanosine and abacavir + saquinavir/ritonavir + didanosine [34].

\section{Ethical issues}

The study protocol was approved by the ethics committees of the Muhimbili University College of Health Sciences and Muhimbili National Hospital, Dar es salaam, Tanzania. Informed verbal consent was sought from participants and from parents/or guardians in case of children below eighteen years. The following information was given to ensure that patients and parents/guardians have the information needed to make an informed choice: a complete description of the aims of the study, potential benefits and risks, blood collection procedures and assurance of confidentiality of any information given as well as test results. Study personnel provided any other requested additional information. All patients seen in this study received appropriate care and treatment according to national guidelines on care and treatment of HIV infected individuals. Patients who were found to have any oral lesions were referred to the Department of Oral Surgery and Oral Pathology of the Muhimbili National Hospital where appropriate management and follow-up were given. All patients' information and test results were confidentially kept.

\section{Statistical analysis}

Data were coded, entered, cleaned, validated and analyzed using the SPSS version 12.0 [39]. Patients were categorized into children ( $<18$ years) and adults ( $\geq 18$ years) and into those on HAART and those not receiving HAART. Comparison of proportions was performed using the Pearson chi-squared test and in situation where $20 \%$ or more of the cells had expected count less than 5, Fisher's exact test was used. Bivariate analysis was done using Spearman's rank correlations. A P-value of $<0.05$ was considered significant. The following were determined: degree of associations between occurrence and types of oral lesions and use of anti-retrovirals, gender, smoking habits, alcohol consumption, coexistence with opportunistic systemic diseases, clinical stage of HIV disease and degree of immunosuppression. Multiple logistic regression analysis was performed to assess the association between presence of oral lesion associated with HIV and use of antiretrovirals after adjusting for CD4+ cell count.

\section{Results}

A total of $532 \mathrm{HIV}$-infected patients, 367 (69\%) females and $165(31 \%)$ males participated in the study (Table 1). There were 51 children aged between 2 and 17 years, with mean age of $7.6(\mathrm{SD} \pm 4.3)$ years and 481 adults aged $18-$ 67 years, with a mean age of $38.2(S D \pm 8.9)$ years. Overall, median CD $4+$ cell count was 151 cells $/ \mathrm{mm}^{3}$, with values ranging from 1 to $2007 \mathrm{cell} / \mathrm{mm}^{3}$. The median CD4+ cell count for children was 501 cells $/ \mathrm{mm}^{3}$ and 134 cells/ $\mathrm{mm}^{3}$ for adults. Majority $373(70.1 \%)$ of children and adult patients were in the WHO clinical stages II to III. Among the participants, 298 (56\%) patients were on HAART, consisting of nucleoside reverse transcriptase inhibitors (NRTIs), non-nucleoside reverse transcriptase inhibitors (NNRTIs) and protease inhibitors (PIs). Majority $531(99.7 \%)$ were on the first line HAART combination, of whom 229 (76.8\%) were on a combination of Stavudine/Lamivudine/Nevirapine, 32 (10.7\%) on a combination of Zidovudine/Lamivudine/Effavirenz, 26 $(8.7 \%)$ on Stavudine/Lamivudine/Effavirenz and 10 (3.4\%) were on Zidovudine/Lamivudine/Nevirapine. One patient $(0.3 \%)$ was on second line combination that included protease inhibitors (Abacavir/Lopinavir/Didanosine). Two hundred and thirty four (44\%) patients were not receiving HAART. Sixty-two patients (11.7\%) reported use of traditional medicines, of whom 36 (58\%) were concomitantly using traditional medicines with HAART.

A total of 237 HIV-associated oral lesions were observed in $210(39.5 \%)$ patients. Overall, oral candidiasis was the commonest oral lesion seen in 125 (23.5\%) patients followed by mucosal hyper pigmentation 25 (4.7\%), parotid gland enlargement 21 (3.9\%) and oral Kaposi's sarcoma $17(3.2 \%)$ (Table 2$)$. In children, parotid gland enlarge- 
Table I: Socio-demographic, treatment, WHO clinical stage and CD4 cell counts of study participants

\begin{tabular}{|c|c|c|c|c|}
\hline Characteristics & All patients $\mathrm{n}(\%)$ & Patients with oral lesions n (\%)* & $\chi^{2}$-value & p-value** \\
\hline \multicolumn{5}{|l|}{ Gender } \\
\hline Male & $165(31.0)$ & $63(38.2)$ & 0.17 & 0.68 \\
\hline Female & $367(69.0)$ & $147(40.1)$ & & \\
\hline \multicolumn{5}{|l|}{ Age (Years) } \\
\hline Children 2-17 & $5 I(9.6)$ & $2 \mid(4 \mid .2)$ & 0.68 & 0.88 \\
\hline Adults $18-67$ & $481(90.4)$ & $189(39.3)$ & & \\
\hline \multicolumn{5}{|l|}{ Smoking habit } \\
\hline Current & $20(3.8)$ & $14(70)$ & 8.17 & 0.02 \\
\hline Stopped & $17(3.2)$ & $7(4 \mid .2)$ & & \\
\hline Never & $495(93.0)$ & $189(38.2)$ & & \\
\hline \multicolumn{5}{|l|}{ Alcohol consumption } \\
\hline Current & $3 \mid(5.8)$ & $10(32.3)$ & & \\
\hline Stopped & $37(7.0)$ & $16(43.2)$ & 0.90 & 0.64 \\
\hline Never & $464(87.2)$ & $184(39.6)$ & & \\
\hline \multicolumn{5}{|l|}{ Traditional medicine } \\
\hline Yes & $62(11.7)$ & $25(40.3)$ & 0.17 & 0.68 \\
\hline No & $470(88.3)$ & $183(38.9)$ & & \\
\hline \multicolumn{5}{|l|}{ Antiretroviral therapy } \\
\hline Without therapy & $234(44.0)$ & $127(54.3)$ & 38.30 & 0.00 \\
\hline HAART therapy & $298(56.0)$ & $83(27.9)$ & & \\
\hline \multicolumn{5}{|l|}{ Antiretroviral types } \\
\hline Stav/Lamiv/Nev & $229(76.8)$ & $9(12.9)$ & 2.96 & 0.57 \\
\hline Stav/Lamiv/Eff & $26(8.7)$ & $10(38.5)$ & & \\
\hline Zido/Lamiv/Eff & $32(10.7)$ & II (34.4) & & \\
\hline Zido/Lamiv/Nev & $10(3.4)$ & $2(20.0)$ & & \\
\hline Abac/Lop/Didan & I $(0.3)$ & $0(0)$ & & \\
\hline \multicolumn{5}{|l|}{ WHO HIV clinical stage } \\
\hline Stage I & $70(13.2)$ & $9(12.9)$ & & \\
\hline Stage II & $204(38.3)$ & $38(18.6)$ & 120.93 & 0.00 \\
\hline Stage III & $169(31.8)$ & $101(59.8)$ & & \\
\hline Stage IV & $89(16.7)$ & $62(69.7)$ & & \\
\hline \multicolumn{5}{|l|}{$\mathrm{CD4}^{+}$cell count $\left(\right.$cells $\left./ \mathrm{mm}^{3}\right)$} \\
\hline$>500$ & $46(8.6)$ & $10(21.7)$ & & \\
\hline $200-500$ & $164(30.8)$ & $33(20.5)$ & 52.45 & 0.00 \\
\hline$<200$ & $322(60.5)$ & $167(31.9)$ & & \\
\hline Total number of patients & $532(100)$. & $210(39.5)$ & & \\
\hline
\end{tabular}

$*$ Row percentages; $* *$ p-value less than 0.05 was considered significant; $\chi^{2}$ Chi square test

ment was the commonest oral lesion (19.6\%), followed by oral candidiasis $(11.8 \%)$, oral Kaposi's sarcoma $(3.9 \%)$, oral hairy leukoplakia $(3.9 \%)$, herpes simplex lesions (2.2\%) and oral warts was the least $(2.0 \%)$. In adults, oral candidiasis was the commonest $(24.7 \%)$, followed by mucosal hyperpigmentation (5.2\%), herpes zoster face and odontogenic abscess was the least $(0.4 \%$ each). There was statistically significant difference in the occurrence of oral candidiasis $\left(\mathrm{X}^{2}=4.31 ; \mathrm{df}=1 ; \mathrm{p}<0.05\right)$ and parotid enlargement $\left(\mathrm{X}^{2}=36.5\right.$; $\left.\mathrm{df}=1 ; \mathrm{p}<0.05\right)$ between children and adults. Pseudomembranous candidiasis was the most predominant type of oral candidiasis $66.4 \%$ (83/125) followed by a combination of pseudomembranous and erythematous 12\% (15/125), erythematous candidiasis $9.6 \%$ (12/125), angular cheilitis $3.2 \%(4 / 125)$, combination of angular cheilitis with erythematous and hyperplastic variant were the least $(1.6 \%$ each). Among 125 patients diagnosed with oral candidiasis $42(33.6 \%)$ patients had previous history of oral candidiasis, 37 (29.6\%) patients presented with esophageal symptoms such as dysphagia, odynophagia and chest pain at the time of examination.

Table 3 shows no significant difference in prevalence of oral lesions among children on HAART and those not on HAART $(\mathrm{OR}=0.35 ; 95 \% \mathrm{CI}=0.11-1.15 ; \mathrm{p}>0.05)$. Table 4 shows that adult patients who were on HAART had a significantly lower risk of oral lesions $(\mathrm{OR}=0.32 ; 95 \% \mathrm{CI}=$ $0.22-0.47 ; \mathrm{p}<0.01)$, oral candidiasis $(\mathrm{OR}=0.28 ; 95 \% \mathrm{CI}$ $=0.18-0.44 ; \mathrm{p}<0.01)$ and oral hairy leukoplakia $(\mathrm{OR}=$ $0.18 ; 95 \% \mathrm{CI}=0.04-0.85 ; \mathrm{p}<0.03)$. There was also lower prevalence of necrotizing ulcerative gingivitis, herpes simplex lesions, recurrent ulcers, Bell's palsy and herpes zoster of face in adult patients who were on HAART, 
Table 2: Occurrence of HIV-associated oral lesions among children and adults

\begin{tabular}{llll}
\hline Oral lesion & Children (2-17 yrs) n (\%) & Adults (18-67 yrs) $\mathbf{n}(\%)$ & Total (n= 532) $\mathbf{n}(\%)$ \\
\hline Oral candidiasis & $6(11.8)$ & $119(24.7)$ & $125(23.5)$ \\
Hyperpigmentation & $0(0)$ & $25(5.2)$ & $25(4.7)$ \\
Enlarged Parotid gland & $10(19.6)$ & $11(2.3)$ & $21(3.9)$ \\
Oral Kaposi's sarcoma & $2(3.9)$ & $15(3.1)$ & $17(3.2)$ \\
Necrotizing Ulcerative gingivitis & $0(0)$ & $13(2.7)$ & $13(2.4)$ \\
Oral hairy leukoplakia & $2(3.9)$ & $10(0.6)$ & $12(2.3)$ \\
Herpes simplex lesions & $7(2.2)$ & $2(2.1)$ & $9(1.7)$ \\
Recurrent ulcers & $0(0)$ & $4(0.8)$ & $4(0.8)$ \\
Oral warts & $1(2.0)$ & $3(0.6)$ & $4(0.8)$ \\
Bell's palsy & $0(0)$ & $3(0.6)$ & $3(0.6)$ \\
Herpes zoster face & $0(0)$ & $2(0.4)$ & $2(0.4)$ \\
Odontogenic abscess & $0(0)$ & $2(0.4)$ & $2(0.4)$ \\
All oral lesions & $\mathbf{2 1}(\mathbf{4 1 . 2 )}$ & $\mathbf{1 8 9 ( 3 9 . 3 )}$ & $\mathbf{2 1 0 ( 3 9 . 5 )}$ \\
\hline
\end{tabular}

but the difference was not statistically significant $(\mathrm{p}>$ 0.05). After controlling for CD4+ cell count, adult on HAART had a significantly lower risk of oral Kaposi's sarcoma compared with those not on HAART (adjusted OR $=0.29 ; 95 \% \mathrm{CI}=0.10-0.89 ; \mathrm{p}<0.03)$. The odds for oral warts and mucosal hyper pigmentation were non-significant higher in adult who were on HAART, being (OR = $1.49 ; 95 \% \mathrm{CI}=0.13-16.5 ; \mathrm{p}>0.05)$ and $(\mathrm{OR}=1.62$; $95 \% \mathrm{CI}=0.68-3.82 ; \mathrm{p}>0.05)$, respectively.

The duration of use of HAART ranged from 1 to 14 months, with majority $(71.1 \%)$ having been on treatment for one to six months. Patients on HAART for the duration of more than six months had significantly lower prevalence of oral lesions $(\mathrm{OR}=0.53 ; 95 \%$ CI $0.29-0.97$; $\mathrm{p}<$
$0.05)$ and specifically oral candidiasis ( $\mathrm{OR}=0.53 ; 95 \% \mathrm{CI}$ 0.29-0.97; $\mathrm{p}=0.04$ ).

The mean CD4+ profiles of patients on HAART and those not on HAART are shown in Table 5. Overall, the majority $(67.8 \%)$ of patients who were on HAART had CD4+ cell count $<200$ cells $/ \mathrm{mm}^{3}$. Only a small minority $(32.2 \%)$ of the patients on HAART were found to have $\mathrm{CD} 4{ }^{+}$counts $>$ 200 cells $/ \mathrm{mm}^{3}$. Among those who were not on HAART $51.3 \%$ had $\mathrm{CD} 4{ }^{+}$cell count $<200$ cells $/ \mathrm{mm}^{3}$ while the rest in the group had $\mathrm{CD} 4{ }^{+}$cell count $>200$ cells $/ \mathrm{mm}^{3}$. However, the majority $(70.3 \%)$ of adult patients on HAART had CD $4+$ cell count $<200$ cells $/ \mathrm{mm}^{3}$ while only minority (36.4\%) of the children on HAART had CD4 ${ }^{+}$cell count $<$ 200 cells $/ \mathrm{mm}^{3}$. The mean difference of CD4+ cell counts

Table 3: Comparison of oral lesions among children on HAART $(n=22)$ and those not on HAART $(n=29)$

\begin{tabular}{|c|c|c|c|c|}
\hline Type of oral lesions & No. of oral lesions n (\%) & Unadjusted OR $(95 \% \mathrm{Cl})$ & Adjusted OR (95\% Cl) & p-value \\
\hline \multicolumn{5}{|l|}{ Oral candidiasis } \\
\hline On HAART & $0(0.0)$ & $0.0(0.0-9.20)$ & $0.0(0.0-1.80)$ & 0.80 \\
\hline Not on HAART & $6(20.7)$ & & & \\
\hline \multicolumn{5}{|c|}{ Enlarged Parotid gland } \\
\hline On HAART & $4(18.2)$ & $0.8(0.2-3.48)$ & $0.9(0.22-3.93)$ & 0.82 \\
\hline Not on HAART & $6(20.7)$ & & & \\
\hline \multicolumn{5}{|l|}{ Oral Kaposi's sarcoma } \\
\hline On HAART & I (4.5) & $1.3(0.08-22.6)$ & $0.9(0.05-17.4)$ & 0.84 \\
\hline Not on HAART & I (3.4) & & & \\
\hline \multicolumn{5}{|l|}{ Oral hairy leukoplakia } \\
\hline On HAART & $0(0.0)$ & $0.0(0.0-2.61)$ & $0.0(0.0-2.11)$ & 0.88 \\
\hline Not on HAART & $10(6.9)$ & & & \\
\hline \multicolumn{5}{|c|}{ Herpes simplex lesions } \\
\hline On HAART & $0(0.0)$ & $0.0(0.0-1.52)$ & $0.0(0.0-7.30)$ & 0.92 \\
\hline Not on HAART & $\mathrm{I}(3.4)$ & & & \\
\hline \multicolumn{5}{|l|}{ Oral warts } \\
\hline On HAART & I (4.5) & - & - & 0.91 \\
\hline Not on HAART & $0(0.0)$ & & & \\
\hline
\end{tabular}


Table 4: Comparison of oral lesions among adults on HAART $(n=276)$ and those not on HAART $(n=205)$

\begin{tabular}{|c|c|c|c|c|}
\hline Type of oral lesions & No. of oral lesions $\mathrm{n}(\%)$ & Unadjusted OR (95\% Cl) & Adjusted OR (95\% Cl) & p-value \\
\hline \multicolumn{5}{|l|}{ Oral candidiasis } \\
\hline On HAART & $4 \mid(\mid 4.9)$ & $0.28(0.18-$ & $0.17(0.11-0.28)$ & 0.00 \\
\hline Not on HAART & $78(38.0)$ & $0.44)$ & & \\
\hline \multicolumn{5}{|l|}{ Hyper pigmentation } \\
\hline On HAART & $17(6.2)$ & $1.62(0.68-$ & $\mathrm{I} .60(0.67-3.8 \mathrm{I})$ & 0.27 \\
\hline Not on HAART & $8(3.9)$ & $3.82)$ & & \\
\hline \multicolumn{5}{|c|}{ Enlarged Parotid gland } \\
\hline On HAART & $6(2.2)$ & $0.89(0.27-$ & $0.92(0.27-3.10)$ & 0.85 \\
\hline Not on HAART & $5(4.9)$ & $2.95)$ & & \\
\hline \multicolumn{5}{|c|}{ Oral Kaposi's sarcoma } \\
\hline On HAART & $5(1.8)$ & $0.36(0.12-$ & $0.29(0.10-0.89)$ & 0.06 \\
\hline Not on HAART & $10(4.9)$ & $1.06)$ & & $*(0.03)$ \\
\hline \multicolumn{5}{|c|}{ Necrotizing Ulcerative gingivitis } \\
\hline On HAART & $5(1.7)$ & $0.45(0.15-1.4 I)$ & $0.37(0.12-1.15)$ & 0.17 \\
\hline Not on HAART & $8(3.4)$ & & & \\
\hline \multicolumn{5}{|l|}{ Oral hairy leukoplakia } \\
\hline On HAART & $2(0.7)$ & $0.18(0.04$ & $0.15(0.03-0.70)$ & 0.03 \\
\hline Not on HAART & $8(3.9)$ & $0.85)$ & & \\
\hline \multicolumn{5}{|c|}{ Herpes simplex lesions } \\
\hline On HAART & $3(1.1)$ & $0.44(0.10$ & $0.39(0.09-1.69)$ & 0.26 \\
\hline Not on HAART & $5(2.4)$ & $1.86)$ & & \\
\hline \multicolumn{5}{|l|}{ Recurrent ulcers } \\
\hline On HAART & I (0.4) & $0.24(0.02-$ & $0.22(0.02-2.15)$ & 0.22 \\
\hline Not on HAART & $3(1.54)$ & $2.37)$ & & \\
\hline \multicolumn{5}{|l|}{ Oral warts } \\
\hline On HAART & $2(0.7)$ & $1.49(0.13-$ & $1.44(0.13-16.4)$ & 0.75 \\
\hline Not on HAART & $\mathrm{I}(0.5)$ & 16.5) & & \\
\hline \multicolumn{5}{|l|}{ Bell's palsy } \\
\hline On HAART & $0(0.0)$ & - & - & 0.84 \\
\hline Not on HAART & $3(1.5)$ & & & \\
\hline \multicolumn{5}{|l|}{ Herpes zoster face } \\
\hline On HAART & $0(0.0)$ & - & - & 0.85 \\
\hline Not on HAART & $2(0.9)$ & & & \\
\hline \multicolumn{5}{|l|}{ Odontogenic abscess } \\
\hline On HAART & $\mathrm{I}(0.4)$ & $0.74(0.04-11.9)$ & $0.78(0.05-13.0)$ & 0.83 \\
\hline Not on HAART & $\mathrm{I}(0.5)$ & & & \\
\hline
\end{tabular}

* p-value obtained after adjusting for CD4+ cell counts.

between the adult and children on HAART and those not on HAART was statistically significant $(\mathrm{t}=3.94 ; 95 \% \mathrm{CI}=$ 42.3 - 126.3; $\mathrm{p}<0.01)$. In both HAART and non-HAART receiving children and adult patients oral lesions occurred more significantly among those with CD4+ cell count less than 200 cell $/ \mathrm{mm}^{3}\left(\chi^{2}=52.4 ; \mathrm{df}=2 ; \mathrm{p}<0.01\right)$. There was a strong association between the WHO clinical stage of HIV disease with the presence of oral lesions $\left(\chi^{2}=121\right.$; df $=3 ; \mathrm{p}<0.01)$, particularly oral candidiasis $\left(\chi^{2}=112 ; \mathrm{df}=\right.$ 3 ; $\mathrm{p}<0.01)$, oral Kaposi's sarcoma $\left(\chi^{2}=121 ; \mathrm{df}=3 ; \mathrm{p}<\right.$ $0.01)$, and oral hairy leukoplakia $\left(\chi^{2}=10 ; \mathrm{df}=3 ; \mathrm{p}<\right.$ $0.05)$.

Eighty-four (15.8\%) patients had current systemic diseases at the time of examination. Sixty-two (11.7\%) patients had pulmonary tuberculosis (TB) and were on anti-tuberculosis treatment. Other systemic opportunistic diseases encountered at the time of examination were; pneumonia $14(2.6 \%)$ patients and herpes zoster 8 $(1.5 \%)$ patients. One hundred and thirty eight $(25.9 \%)$ reported history of herpes zoster infection, 84 patients $(15.8 \%)$ pneumonia while cryptococcal meningitis was reported by only 10 patients $(1.9 \%)$. There was a significant association between occurrence of pulmonary TB with oral lesions $\left(\chi^{2}=6.9 ; \mathrm{df}=1 ; \mathrm{p}<0.01\right)$ and oral candidiasis $\left(\chi^{2}=11.0 ; \mathrm{df}=1 ; \mathrm{p}<0.01\right)$ but not other systemic diseases $(P>0.05)$. Oral lesions were not associated with any of the investigated socio-demographic features except for tobacco smoking $\left(\chi^{2}=8.17 ; \mathrm{df}=2 ; \mathrm{p}<0.01\right)$.

\section{Discussion}

In the present study, the prevalence of HIV-associated oral lesions in adult patients receiving HAART was significantly reduced. The reduction was mainly attributed to 
Table 5: CD4+ cell counts of Patients on HAART and those not on HAART

\begin{tabular}{|c|c|c|c|c|c|c|}
\hline & \multicolumn{3}{|c|}{ Patients on HAART $(n=298)$} & \multicolumn{3}{|c|}{ Patients without HAART $(n=234)$} \\
\hline & n (\%) & Mean & SD & n (\%) & Mean & SD \\
\hline \multicolumn{7}{|c|}{ CD4+ cell count (cells/mm³) } \\
\hline$<200$ & $202(67.8)$ & 84.0 & 62.1 & $120(51.3)$ & 65.2 & 57.0 \\
\hline $200-500$ & $80(26.8)$ & 296.0 & 75.0 & $84(35.9)$ & 314.4 & 90.2 \\
\hline$>500$ & $16(5.4)$ & $7 \mid 4.1$ & 207.1 & $30(12.8)$ & 879.9 & 415.2 \\
\hline Total & 298 & 174.8 & 177.5 & 234259.1 & 310.0 & 470 \\
\hline
\end{tabular}

Student's t-test for comparing means; $(t=3.94 ; 95 \% \mathrm{Cl}=42.3-126.3 ; \mathrm{p}=0.00)$.

the reduction of oral candidiasis and oral hairy leukoplakia among adult patients. This finding is consistent with observations in other studies that have shown significant reduction in these oral lesions associated with HAART usage, linked to the improved immune status of patients $[12,13,15-22]$. Notably, patients on HAART for the duration of more than six months had significantly lower prevalence of oral lesions $(\mathrm{OR}=0.53 ; 95 \% \mathrm{CI} 0.29-0.97 ; \mathrm{p}<$ $0.05)$ and specifically oral candidiasis $(\mathrm{OR}=0.53 ; 95 \% \mathrm{CI}$ $0.29-0.97 ; \mathrm{p}=0.04)$. There was, however, no significant association between the type of HAART regimen and presence of oral lesions, most probably due to the fact that most of our patients $(76.8 \%)$ were on one type of HAART consisting of stavudine, lamivudine and nevirapine, and that only one patient had a HAART combination containing PI. We found no significant difference in prevalence of oral lesions between children on HAART and those not on HAART (Table 3 ), similar to other studies $[26,27]$. The occurrence of HIV-associated oral in children is an issue that requires further investigation as the results of different studies have produced conflicting results. In one study there was no direct relationship between prevalence of oral lesions, severe immunodepression, and/or viral load $>100000$ copies in children who were perinataly infected with HIV [40].

There were no significant difference in prevalence of oral lesions between adults (39.3\%) and children (41.2\%), ( $\mathrm{p}$ $>0.05$ ). However, a significantly higher prevalence of enlargement of parotid glands in children and oral candidiasis in adults was observed, which is in keeping with the findings of Greenspan et al. 1992 [37].

Mucosal hyperpigmentation, which was the second most prevalent oral lesions after oral candidiasis with a prevalence of $4.7 \%$, occurred at higher, but non-significant magnitude, among adult patients who were on HAART. The reported prevalence of mucosal hyperpigmentation compares with a prevalence of $6 \%$ among HIV/AIDS patients in Kenya [9]. The higher prevalence of mucosal hyperpigmentation in patients on HAART has been linked with increased melanin production in the epithelium associated with increased release of á-melanocyte-stimu- lating hormone (á - MSH) [41] as a result of systemic ketoconazole and zidovudine therapy [42,43]. In the present study $20 \%$ (5/25) of patients with mucosal hyperpigmentation were on HAART combination containing zidovudine.

Likewise, there was insignificant increase in oral papillomata [oral warts] in patients on HAART as compared to the non-HAART group. The increase in oral warts among patients on HAART has been associated with immune reconstitution [18,23-25]. The lack of significant association between oral wart and HAART usage observed in the present study could be due to the short period of the administration of HAART as majority of patients were on HAART for one to six months.

There were no differences in the prevalence of other oral lesions including enlarged parotid glands, necrotizing ulcerative gingivitis, recurrent ulcers, Bell's palsy and herpes zoster of the face between HAART and non-HAART groups ( $p>0.05)$. This could be explained by the fact that most of these lesions are classified as being less commonly associated with HIV [44] and therefore, their prevalence even in the non-HAART receiving group was small.

The use of traditional medicine among our patients was high $(11.7 \%)$, which is approximately one in eight patients, an observation that is in line with that reported earlier in Tanzania [45]. Although no significant association was found between occurrences of oral lesions and use of traditional medicine (Table 1) there is still a need for further studies since many people with HIV/AIDS use traditional medicine in addition to HAART. It is crucial to learn more about the nature and composition of these plant medicines and their potential interactions with drugs that are used for management of HIV/AIDS and its associated opportunistic diseases.

In this study, $15.8 \%$ of patients diagnosed to have systemic diseases such as tuberculosis, pneumonia and herpes zoster at the time of examination. However, the only significant association found was between pulmonary TB and oral lesions, specifically oral candidiasis $(\mathrm{p}<=0.01)$ 
Table 6: Association in the occurrence of oral lesions and opportunistic systemic diseases among HIV-infected patients expressed as Odds ratios (OR) with $95 \%$ Confidence intervals

\begin{tabular}{|c|c|c|c|}
\hline Systemic disease & n (\%) & OR $(95 \% \mathrm{Cl})$ & $\chi^{2}$-value (p-value) \\
\hline Tuberculosis & 62 (1 I.7) & & \\
\hline All oral lesions & $34(54.8)$ & $2.02(1.19-3.46)$ & $6.9(0.008)$ \\
\hline Oral candidiasis & $25(40.3)$ & $2.50(1.44-4.34)$ & $11.0(0.001)$ \\
\hline Pneumonia & $14(2.6)$ & & \\
\hline All oral lesions & $4(28.6)$ & $0.61(0.19-1.96)$ & $0.71(0.40)$ \\
\hline Oral candidiasis & $2(14.3)$ & $0.54(0.12-2.42)$ & $0.68(0.4 \mathrm{I})$ \\
\hline Herpes zoster & 8 (1.5) & & \\
\hline All oral lesions & $2(25.0)$ & $0.5 \mathrm{I}(\mathrm{I} .0 \mathrm{I}-2.53)$ & $0.7 \mid(0.32)$ \\
\hline Oral candidiasis & $2(25.0)$ & $1.08(0.22-5.45$ & $0.01(0.60)$ \\
\hline
\end{tabular}

(Table 6). This association possibly reflects immune deterioration in patients with oral candidiasis and TB. This finding, which is in keeping with that of Nittayananta et al. 2002 [46] who found significant association between the occurrence of $\mathrm{TB}$ and the presence of oral candidiasis (OR 2.8; 95\% CI 1.6-4.8; $P<0.01$ ), and positive predictive values of any oral lesions and oral candidiasis in predicting TB of $87 \%$ (95\% CI 73.0-94.6) and 67\% (95\% CI 51.9-80.0), respectively seem to imply that oral candidiasis might be used as an additional clinical marker for TB together with clinical presentation of weight loss with night sweats and chest symptoms. Majority (25.9\%) reported history of herpes zoster infection, 84 patients $(15.8 \%)$ pneumonia while cryptococcal meningitis was reported by only 10 patients (1.9\%). However, there was no statistically significant difference between prevalence of oral lesions and history of opportunistic systemic diseases $(P>0.05)$. The limitation on this part of the study was dependency on patients to recall previous opportunistic disease.

Lastly, the significant association between occurrence of oral lesions with CD4+ counts $<200$ cells $/ \mathrm{mm}^{3}$ and WHO clinical stage of HIV disease (Table 1) found in this study underscores the prognostic significance of these manifestations in HIV disease.

\section{Conclusion}

In this group of HIV-infected patients, adult patients receiving HAART predominantly combination of stavudine, lamivudine and nevirapine for a period of less than a year, had a significantly lower prevalence of oral lesions, particularly oral candidiasis and oral hairy leukoplakia that was observed. There was also an insignificant increase in prevalence of oral warts and mucosal hyper pigmentation, while the prevalence of other oral lesions was unchanged. However there was no significant change in occurrence of oral lesions in children receiving HAART. More studies preferably longitudinal need to be conducted for longer periods of time in order to get a better picture on the efficacy of HAART in reducing oral lesions in both children and adults in our setting.

\section{Competing interests}

The author(s) declared that they have no competing interests.

\section{Authors' contributions}

All authors were involved in designing the study. OJMH and FM took part in data collection, data handling and preparation of manuscript. MINM, ENMS, MJM, FHM, PEV and AJAM participated in preparation of the manuscript. EK participated in data analysis and preparation of the manuscript. Finally, all authors read and approved the final manuscript.

\section{Acknowledgements}

We would like to thank all the patients who were attending the HIV clinic for their cooperation and willingness to participate in the study. We thank very much Dr. Candida Moshiro of the Department of Biostatistics and Epidemiology of the Muhimbili University College of Health Science for advice on statistics. We also wish to thank the staff of the Muhimbili National Hospital (MNH) HIV clinic and the Department of Oral Surgery and Oral Pathology of Muhimbili National Hospital for their cooperation during the study period. Finally, we wish to thank the Muhimbili University College of Health Sciences (MUCHS) for providing financial support and permission to submit the manuscript for publication.

\section{References}

I. Hodgson TA: HIV-associated oral lesions: prevalence in Zambia. Oral Dis 1997, 3:S46-S50.

2. Tukutuku K, Muyembe-Tamfum L, Kayembe K, Odio W, Kandi K, Ntumba M: Oral manifestations of AIDS in a heterosexual population in a Zaire hospital. J Oral Pathol Med 1990, 19:232-234.

3. Itula PF, Mackenzie SB, Lewis K, Mortimer PP: Orofacial manifestations and seroprevalence of HIV infection in Namibian dental patients. Oral Dis 1997, 3:S5I-S53.

4. Matee MI, Scheutz F, Moshy J: Occurence of oral lesions in relation to clinical and immunological status among HIVinfected adult Tanzanians. Oral Dis 2000, 6:106-1II.

5. Schiodt M, Bakilana PB, Hiza JF, Shao JF, Bygbjerg I, Mbaga I, Vestergaard BF, Nielsen CM, Lauritzen E, Lerche B, Kuijlen K: Oral candidiasis and Hairy leukoplakia correlate with HIV infection in Tanzania. Oral Surg Oral Med Oral Pathol 1990, 69:591-596.

6. Matee MI, Moshi J, Kalyanyama BM: Oro-facial lesions occurring in HIV-infected individuals in Dar es Salaam. East Afr Med Journal 1996, 73:8I3-8I5. 
7. Kamiru NH, Naidoo S: Oral HIV lesions and oral health behaviour of HIV-positive patients attending the Queen Elizabeth II Hospital, Maseru, Lesotho. South African Dental Journal 2002, 57:479-482.

8. Adurogbangba MI, Aderinokun GA, Odaibo GN, Olaleye $\mathrm{OD}$, Lawoyin TO: Oro-facial lesions and CD4 counts associated with HIVIAIDS in an adult population in Oyo State, Nigeria. Oral Dis 2004, 10:319-326.

9. Butt FM, Chindia ML, Vaghela VP, Mandalia K: Oral manifestations of HIVIAIDS in a Kenyan provincial hospital. East Afr Med Journal 200I, 78:398-40I.

10. Jonsson N, Zimmerman M, Chidzonga MM, Jonsson K: Oral manifestations in 100 Zimbabwean HIVIAIDS patients referred to a specialist center. Central Afric Journal of Medicine 1998, 44:3I-34.

II. Arendorf TM, Bredekamp B, Cloete CA, Sauer G: Oral manifestations of HIV infection in $\mathbf{6 0 0}$ South African patients. J Oral Pathol Med 1998, 27: 176-179.

12. Greenspan D, Gange SJ, Phelan JA, Navazesh M, Alves ME, MacPhail LA, Mulligan R, Greenspan JS: Incidence of oral lesions in HIV-Iinfected women: reduction with HAART. J Dent Res 2004 83: $145-150$

13. Schmidt-Westhausen AM, Priepke F, Bergmann FJ, Reichart PA: Decline in the rate of oral opportunistic infections following introduction of highly active antiretroviral therapy. J Ora Pathol Med 2000, $31: 336-341$.

14. Tappuni AR, Fleming G]: The effect of antiretroviral therapy on the prevalence of oral manifestations in HIV-infected patients. A UK study. Oral Surg Oral Med Oral Pathol Oral Radiol Endod 2001, 92:623-628.

15. Ramirez-Amador V, Esquivel-pedraza L, Sierra-Madero J, AnayaSaavedra G, Gonzalez-Ramirez I, Ponce-de-Leon S: The changing clinical spectrum of Human Immunodeficiency Virus [HIV]related oral lesions in 1,000 consecutive patients: A I 2-year study in a referral Center in Mexico. Medicine-[Baltimore] 2003, 82:39-50.

16. Patton LL, McKaig R, Strauss R, Rogers D, Eron JJ: Changing prevalence of oral manifestations of human immunodeficiency virus in the era of protease inhibitor therapy. Oral Surg Oral Med Oral Pathol Oral Radiol Endod 2000, 3 I:299-304.

17. Nicolatou-Galitis O, Velegraki A, Paikos S, Economopoulou P, Stefaniotis T, Papanikolaou IS, Kordossis T: Effect of PI-HAART on the prevalence of oral lesions in HIV-I infected patients. A Greek study. Oral Dis 2004, 10:145-150.

18. Shetty K, Leigh J: The Changing Face of Oral Lesions in HIV/ AIDS Patients Undergoing Highly Active Antiretrovira Treatment. AIDS Patient Care STDS 2000, 1 4:627-635.

19. Hood S, Bonington A, Evans J, Denning D: Reduction in oropharyngeal candidiasis following introduction of protease inhibitors. AIDS 1998, $31: 447-448$.

20. Hoegl L, Thoma-Greber E, Rocken M, Korting HC: HIV protease inhibitors influence the prevalence of oral candidiasis in HIVinfected patients: a 2-year study. Mycoses 1998, 31:32I-5.

21. Revankar SG, Sanche SE, Dib OP, Caceres M, Patterson TF: Effect of highly active antiretroviral therapy on recurrent oropharyngeal candidiasis in HIV-infected patients. AIDS 1998, 3I:25II-3.

22. Dios PD, Ocampo A, Miralles C, Otero I, Iglesias I, Rayo N: Frequency of oropharyngeal candidiasis in HIV-infected patients on protease inhibitor therapy. Oral Surg Oral Med Oral Pathol Oral Radiol Endod 1999, 31:437-44I.

23. Greenspan D, Canchola AJ, MacPhail LA, Cheikh B, Greenspan JS: Effect of highly active antiretroviral therapy on frequency of oral warts. Lancet 357:|4III-I4I2.

24. King MD, Reznik DA, O'Daniels CM, Larsen NM, Osterholt D, Blumberg HM: Human papillomavirus-associated oral warts among human immunodeficiency virus-seropositive patients in the era of highly active antiretroviral therapy: An emerging infection. Clin Infect Dis 2002, 34:64I-648.

25. Eyeson JD, Warnakulasuriya KAAS, Johnson NW: Prevalence and incidence of oral lesions-the changing scene. Oral Dis 2000, 6:267-273

26. Flanagan MA, Barasch A, Koenigsberg SR, Fine D, Houpt M: Prevalence of oral soft tissue lesions in HIV-infected minority children treated with highly active antiretroviral therapies. Pediatric Dentistry 2000, 22:287-291.
27. Khongkunthian $\mathrm{P}$, Grote M, Isaratanan W, Piyaworawong S, Reichart PA: Oral manifestations in 45 HIV-positive children from Northern Thailand. J Oral Pathol and Medicine 200I, 30:549-552.

28. Eyeson JD, Warnakulasuriya KAAS, Johnson NW: Prevalence and incidence of oral lesions-the changing scene. Oral Dis 2000, 6:267-273.

29. Marcus M, Maida CA, Freed JR, Younai F, Coulter ID, Der-Martirosian C, Liu H, Freed B, Guzman-Becerra N, Shapiro M: Oral white patches in a national sample of medical HIV patients in the era of HAART. Com Dent Oral Epid 2005, 33:99-106.

30. Coulter ID, Marcus M, Freed JR, Der-Martirosian C, Cunningham WE, Andersen RM, Maas WR, Garcia I, Schneider DA, Genovese B, Shapiro MF, Bozzette SA: Use of dental care by HIV-infected medical patients. J Dent Res 2000, 79:1356-|36|.

31. Freed JR, Marcus M, Freed BA, Der-Martirosian C, Maida CA, Youna FS, Yamamoto JM, Coulter ID, Shapiro MF: Oral health findings for HIV-infected adult medical patients from HIV cost and service utilization study. JADA 2005, | 36: | 396-| 405.

32. World Health Organisation: Scaling up antiretroviral therapy in resource-limited settings: guidelines for a public health approach. WHO Geneva 2002.

33. The United Republic of Tanzania, Ministry of Health, NACP: Health Sector Strategy for HIVIAIDS [2003-2006]. Dar es Salaam

34. The United republic of Tanzania, Ministry of Health, National AIDS Control Programme [NACP]: National Guidelines for the clinical management of HIV and AIDS. Second2005.

35. World Health Organization: Acquired Immune Deficiency syndrome [AIDS] interim proposal for a WHO staging system for HIV infection and disease. Weekly Epidem Rec 1990, 65:221-228.

36. Krammer IR, Pindborg J], Bezrouukov V, Infirri JS: Guide to epidemiology and diagnosis of oral mucosal diseases and conditions. World Health Organization. Community Dent Oral Epidemiol 1980, 8: I-16.

37. Greenspan JS, Barr CE, Sciubba JJ, Winkler JR: Oral manifestations of HIV infection: definitions, diagnostic criteria and principles of therapy. Oral Med Oral Pathol Oral Radiol 1992, 73:I42-I 44

38. Landay A, Ohlsson-Wilhelm B, Giorgi JV: Application of flow cytometry to the study of HIV infection. AIDS 1990, 4:479-497.

39. SPSS Inc version 12.0: The statistical Package for the Social Sciences. Chicago, II: SPSS Inc; 2004.

40. Okunser C, Einstein A, Badner V, Wiznia A, Rosenberg M: Prevalence of Oral Lesions and Percent CD4 ${ }^{+}$-Lymphocytes in HIV-Infected Children on Antiretroviral Therapy. AIDS Patient Care and STDs 2003, 17:5-II.

41. Bravo IM, Correnti M, Escalona L, Perrone M, Brito A, Tovar V, Rivera $\mathrm{H}$ : Prevalence of oral lesions in HIV patients related to CD4 cell count and viral load in a Venezuelan population. Med Oral Patol Oral Cir Bucal 2006, I I :33-39.

42. Ficarra G, Shillitoe EJ, Adler-Storthz K, Gaglioti D, Di Pietro M, Riccardi R, Forti G: Oral melanotic macules in patients infected with HIV. Oral Surg Oral Med Oral Pathol 1990, 70:748-755.

43. Langford A, Pohle HD, Gelderblom H, Zhang X, Reichart PA: Oral hyperpigmentation in HIV-infected patients. Oral Surg Oral Med Oral Pathol 1989, 67:30I-7.

44. EC Clearinghouse on oral problems related to HIV infection and WHO collaborating centre on oral manifestations of the Immunodeficiency Virus: Classification and diagnostic criteria for oral lesions in HIV infection. J Oral Pathol Med I993, 22:289-291.

45. Kilima PM, Ostermayer I, Shija M, Wolff MM, Evans PJ: Drug utilization, prescribing habits and patients in City Council Health Facilities, Dar es Salaam, Tanzania. DUHP, Swiss Tropicallnstitute, Basel; 1993:19.

46. Nittayananta W, Chanowanna N, Winn T, Silpapojakul K, Rodklai A Jaruratanasirikul S, Liewchanpatana K: Co-existence between oral lesions and opportunistic systemic diseases among HIVinfected subjects in Thailand. J Pathol Med 2002, 31:163-168.

\section{Pre-publication history}

The pre-publication history for this paper can be accessed here:

http://www.biomedcentral.com/1472-6831/6/12/prepub 